\title{
Faktor-Faktor yang Mempengaruhi Gangguan Perkembangan Neurologis pada Bayi dengan Riwayat Hiperbilirubinemia
}

\author{
Baginda Hutahaean, Alifiani Hikmah Putranti, Kamilah Budhi Rahardjani, \\ Magdalena Sidhartani \\ Bagian Ilmu Kesehatan Anak, Fakultas Kedokteran Universitas Diponegoro, RSUP Dr. Kariadi, Semarang
}

\begin{abstract}
Latar belakang. Salah satu penyebab gangguan perkembangan neurologis (GPN) adalah hiperbilirubinemia. Kerusakan sawar darah otak (SDO) meningkatkan permeabilitas otak terhadap bilirubin. Terdapat beberapa faktor yang menyebabkan kerusakan SDO, yang selanjutnya meningkatkan risiko GPN bayi.

Tujuan. Mengetahui faktor risiko yang mempengaruhi GPN pada bayi dengan riwayat hiperbilirubinemia. Metode. Desain longitudinal prospektif, subjek 48 neonatus dengan kadar bilirubin indirek serum (BIS) $>10 \mathrm{mg} / \mathrm{dL}$, dirawat Oktober 2004-Agustus 2005, dan dipantau pada usia 3, 6 dan 9 bulan dengan Bayley Infant Neurodevelopmental Screener (BINS). Multivariat cox-regression digunakan untuk analisis.

Hasil. Receiver operating curve (ROC) : kadar BIS neonatal dapat sebagai prediktor GPN bayi, dengan cut-off point BIS 14,68 mg/dL. Terdapat hubungan bermakna antara BIS dengan GPN $\left(\chi^{2}: 18,657 ; \mathrm{p}<0,001\right)$. Dari uji multivariat Cox-regression : infeksi (Hazard ratio/HR 4.0;CI=0.9;18,1), kadar BIS >14,68 mg/dL (HR 2,5;CI=0.5;12,1) dan tidak mendapat terapi $(H R 2.1 ; \mathrm{CI}=0.8 ; 5,6)$ mempunyai risiko GPN. Asidosis dan hipoglikemia bukan faktor risiko.

Kesimpulan. Kadar BIS dapat digunakan sebagai prediktor GPN. Infeksi, kadar BIS >14,68 mg/dL dan tidak mendapat terapi merupakan faktor yang meningkatkan risiko GPN pada bayi dengan riwayat hiperbilirubinemia. (Sari Pediatri 2007; 9(3):201-206).
\end{abstract}

Kata kunci: gangguan perkembangan neurologis, hiperbilirubinemia, sawar darah otak

\footnotetext{
Alamat korespondensi

Dr. Alifiani Hikmah Putranti, Sp.A(K).

Lab. IKA FK-UNDIP/RSUP Dr. Kariadi, Jl. Dr. Soetomo 16-18 Semarang.

Tel. 024- 8414296 Fax. 024- 8414296
}

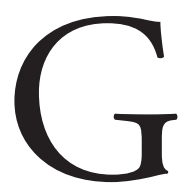

angguan perkembangan neurologis (GPN) adalah kegagalan kemampuan fungsi 7 neurologis yang seharusnya dimiliki, yang disebabkan adanya defek otak pada periode awal pertumbuhan otak. Penyebab gangguan ini dapat terjadi pada masa pranatal, perinatal atau pasca natal. ${ }^{1,2,3}$ 
Jumlah kasus GPN saat ini meningkat dengan makin baiknya perawatan di bidang Neonatologi dan makin canggihnya alat-alat diagnostik. Ditemukan 20\%-30\% kasus di Bagian Anak dengan gangguan neurologis. ${ }^{1}$ Salah satu penyebab GPN pada masa perinatal yang sering adalah hiperbilirubinemia. ${ }^{4,5}$ Hiperbilirubinemia adalah kadar bilirubin total serum (BTS) $>5 \mathrm{mg} / \mathrm{dL}(86 \mu \mathrm{mol} / \mathrm{L}) .{ }^{6}$ Hiperbilirubinemia dapat menimbulkan keracunan otak yang menyebabkan kerusakan neuron permanen. Peran bilirubin indirek serum (BIS) penting karena bersifat neurotoksik. Gomella menetapkan hiperbilirubinemia indirek bila kadar BIS $>12,9 \mathrm{mg} / \mathrm{dL}$ pada bayi aterm dan $>15 \mathrm{mg} / \mathrm{dL}$ pada bayi preterm. Secara umum seorang bayi dianggap bermasalah bila kadar $\mathrm{BIS} \geq 10$ $\mathrm{mg} / \mathrm{dL}$. Secara invitro dan invivo, BIS dalam konsentrasi tinggi dapat berdifusi melewati sawar darah otak (SDO) . $^{6,7,8,9}$

Sawar darah otak (SDO) mengatur masuknya bilirubin ke otak dan mencegah difusi zat-zat tertentu dari pembuluh darah ke jaringan otak. ${ }^{10}$ Kerusakan SDO meningkatkan permeabilitas otak terhadap bilirubin. Terdapat beberapa faktor yang menyebabkan kerusakan SDO, yang selanjutnya meningkatkan risiko GPN bayi, antara lain asfiksia, hipoksia, asidosis, hipoperfusi, hipoosmolaritas, infeksi/sepsis, hipoglikemia, trauma kepala, prematuritas, dan sebagainya. ${ }^{3,6,7,11}$

\section{Metode}

Penelitian observasional dengan rancangan longitudinal prospektif, yang bertujuan untuk mengetahui faktor risiko yang mempengaruhi GPN pada bayi dengan riwayat hiperbilirubinemia. Subjek penelitian adalah 48 neonatus dengan hiperbilirubinemia indirek yang dirawat di bangsal Perawatan Bayi Risiko Tinggi (PBRT) RSUP. Dr. Kariadi Semarang, bulan Oktober 2004-September 2005 dengan kriteria inklusi lahir aterm, lahir spontan, berat badan lahir $>2500 \mathrm{~g}$, kadar BIS $>10 \mathrm{mg} / \mathrm{dL}$, dan bersedia mengikuti penelitian (menandatangani informed consent). Kriteria eksklusi terdapat riwayat penyakit yang dapat mempengaruhi fungsi neurologis (meningitis, ensefalitis, serebral palsi), menderita asfiksia berat, menderita sindrom Down/ kelainan kongenital lain. Subjek dipilih dengan consecutive sampling. Pengamatan dilakukan dengan memeriksa kadar BIS tertinggi selama perawatan dan skrining dengan Bayley Infant Neurodevelopmental
Screener (BINS) pada usia 3, 6 dan 9 bulan, untuk mendeteksi risiko GPN. Multivariat cox-regression digunakan untuk analisis.

\section{Hasil}

Receiver operating curve (ROC) dipakai untuk menilai kadar BIS neonatal sebagai prediktor risiko GPN bayi. Kadar BTS disertakan sebagai pembanding. Hasil ditampilkan pada Gambar 1.

Besar luas area dibawah kurva (area under the curve = AUC) untuk kadar BIS dan BTS neonatal terhadap risiko GPN bayi ditampilkan pada Tabel 1 .

Data pada Gambar 1 dan Tabel 1 menunjukkan bahwa kadar BIS maupun BTS mempunyai AUC $>0,7$ yaitu 0,90 untuk BIS dan 0,89 untuk BTS. Berdasarkan hal tersebut, baik BIS maupun BTS dapat digunakan sebagai prediktor risiko GPN bayi. Namun menimbang luas AUC untuk kadar BIS lebih besar dan secara patofisologi BIS dapat melewati SDO, maka BIS dinilai lebih berperan dalam risiko GPN bayi.

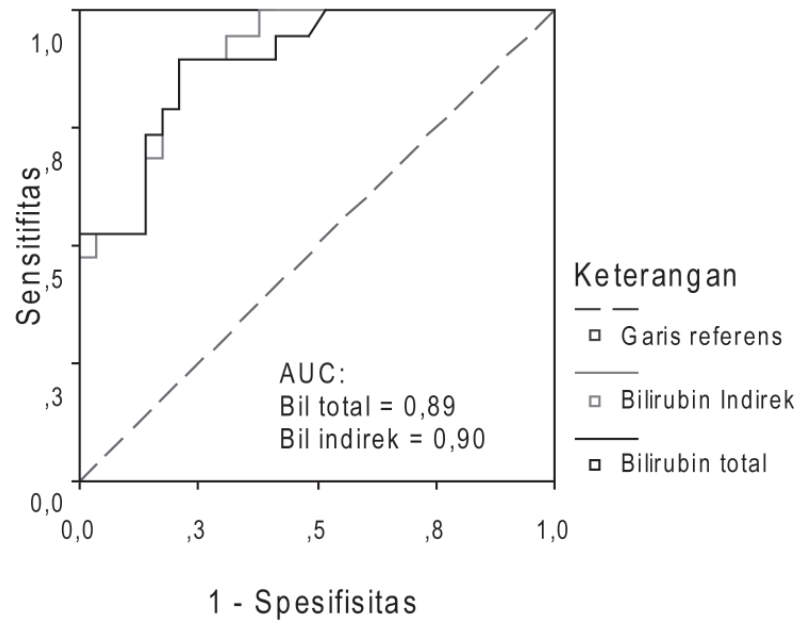

Gambar 1. Kurva ROC BTS dan BIS neonatal terhadap risiko GPN bayi

$\mathrm{AUC}=$ area under the curve $; \mathrm{Bil}=$ bilirubin

Tabel 1. Besar AUC untuk kadar BIS dan BTS

\begin{tabular}{lccc}
\hline \multicolumn{1}{c}{ Variabel } & AUC & $95 \%$ CI & p \\
\hline Bilirubin total (BTS) & 0,89 & $0,80 \mathrm{~s} / \mathrm{d} 0,98$ & $<0,001$ \\
Bilirubin indirek (BIS) & 0,90 & $0,82 \mathrm{~s} / \mathrm{d} 0,98$ & $<0,001$ \\
\hline
\end{tabular}


Dari ROC ditentukan cut-off point kadar BIS neonatal untuk memprediksi risiko GPN bayi adalah $14,68 \mathrm{mg} / \mathrm{dL}$ (Gambar 2). Hubungan antara kadar BIS neonatal berdasarkan kategori risiko GPN bayi ditampilkan pada Tabel 2.

Tabel 2 menunjukkan bahwa ada hubungan bermakna $(\mathrm{p}<0,001)$ antara kadar BIS neonatal yang telah dikategorikan berdasarkan kurva ROC dengan risiko GPN bayi. Faktor-faktor saat neonatal yang dapat berpengaruh terhadap risiko GPN ditampilkan pada Tabel 3.

Dari Tabel 3 diketahui bahwa kadar BIS >14,68 $\mathrm{mg} / \mathrm{dL}$, infeksi, dan tidak mendapat terapi merupakan faktor risiko GPN bayi. Berbeda dengan hal di atas, adanya asfiksia justru merupakan faktor protektif. Namun dari hasil analisis selanjutnya, diketahui bahwa pada penelitian ini bayi dengan riwayat asfiksia memiliki kadar BIS lebih rendah dibanding dengan yang tidak. Pada Tabel 4 secara statistik tidak dijumpai perbedaan bermakna antara kadar BIS neonatal yang memiliki riwayat asfiksia dengan yang tidak $(\mathrm{p}=0,08)$.

Untuk mengetahui pengaruh masing-masing variabel di atas secara bersama-sama terhadap risiko GPN bayi, dilakukan uji multivariat cox-regression; besaran adjusted risk dinyatakan sebagai rasio hazard. Analisis bivariat pada Tabel 3 dijumpai adanya variabel yang hubungannya tidak bermakna dengan risiko GPN pada bayi, karena secara patofisiologi variabel tersebut diketahui turut berpengaruh terhadap risiko GPN pada bayi, maka seluruh variabel pada Tabel 3 diikutsertakan dalam analisis. Besarnya rasio hazard ditampilkan pada Tabel 5.

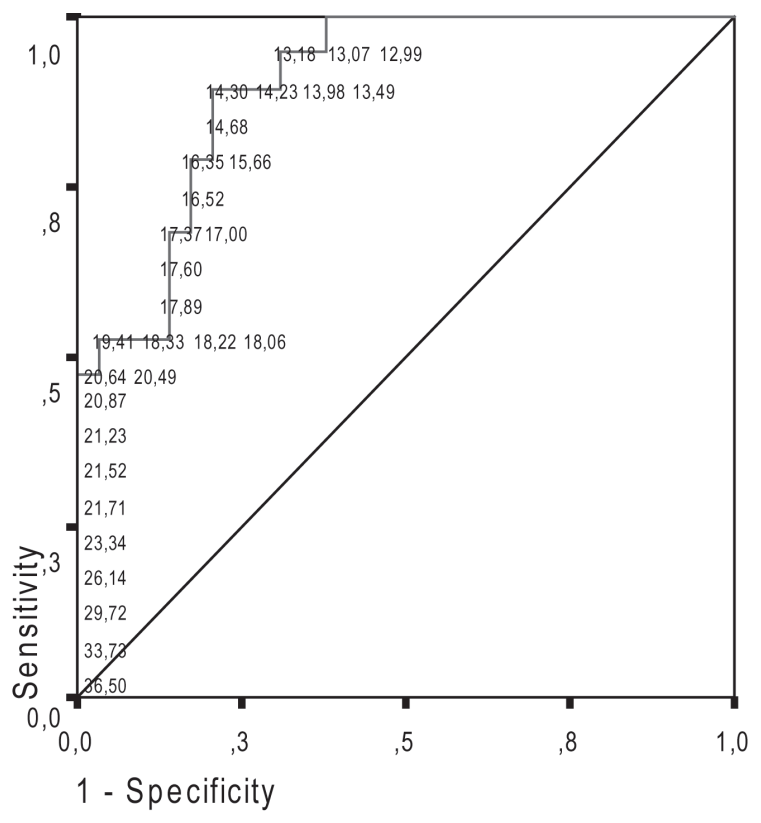

Gambar 2. Kurva cut-off point kadar BIS neonatal untuk memprediksi risiko GPN

Tabel 2. Tabel silang kategori kadar BIS neonatal berdasarkan cut-off point 14,68 mg/dL terhadap risiko GPN bayi

\begin{tabular}{lccc}
\hline & \multicolumn{2}{c}{ Risiko GPN } & \\
\cline { 2 - 3 } Kategori BIS & $\begin{array}{c}\text { Tidak ada } \\
\mathrm{n}(\%)\end{array}$ & $\begin{array}{c}\text { Ada } \\
\mathrm{n}(\%)\end{array}$ & $\begin{array}{c}\text { Total } \\
\mathrm{n}(\%)\end{array}$ \\
\hline$\leq 14,68$ & $23(88,5)$ & $3(11,5)$ & $26(100,0)$ \\
$>14,68$ & $6(27,3)$ & $16(72,7)$ & $22(100,0)$ \\
\hline Total & $29(60,4)$ & $19(39,6)$ & $48(100,0)$ \\
\hline
\end{tabular}

$\chi^{2}=18,657 ; \mathrm{df}=1 ; \mathrm{p}<0,001$

Tabel 3. Faktor neonatal yang dapat berpengaruh terhadap risiko GPN

\begin{tabular}{lcccc}
\hline \multirow{2}{*}{ Variabel } & \multicolumn{2}{c}{ GPN } & \\
\cline { 2 - 3 } & $\begin{array}{c}\text { Tidak ada } \\
\mathrm{n}(\%)\end{array}$ & $\begin{array}{c}\text { Ada } \\
\mathrm{n}(\%)\end{array}$ & $\mathrm{RR}(95 \% \mathrm{CI})$ & $\mathrm{p}$ \\
\hline BIS & & & & \\
$-\leq 14,68$ & $23(88,5)$ & $3(11,5)$ & 1 & \\
$->14,68$ & $6(27,3)$ & $16(72,7)$ & $6,3(2,1-18,8)$ & $<0,001$ \\
Infeksi & $10(37,0)$ & $17(63,0)$ & $6,6(1,7-25,5)$ & $<0,001$ \\
Asidosis & $6(46,2)$ & $7(53,8)$ & $1,5(0,80-3,1)$ & 0,2 \\
Asfiksia sedang & $20(74,1)$ & $7(25,9)$ & $0,5(0,2-0,9)$ & 0,03 \\
Hipoglikemia & $3(60,0)$ & $2(40,0)$ & $1,0(0,3-3,1)$ & 0,98 \\
Terapi & & & & \\
$\quad$ - Fototerapi dengan atau & $20(90,9)$ & $2(9,1)$ & & 1 \\
$\quad$ tanpa transfusi tukar & $9(34,6)$ & $17(65,4)$ & $7,2(1,9-27,8)$ & $<0,001$ \\
\hline
\end{tabular}


Tabel 4. Rerata kadar BIS neonatal dan riwayat asfiksia

\begin{tabular}{lc}
\hline \multicolumn{1}{c}{ Riwayat asfiksia } & Kadar BIS $(\mathrm{mg} / \mathrm{dL})$ \\
& Rerata $(\mathrm{SD})$ \\
\hline Tidak ada & $18,3(7,2)$ \\
Ada & $14,3(3,2)$ \\
\hline
\end{tabular}

Uji Mann-Whitney : $\mathrm{p}=0,08$

Tabel 5. Rasio Hazard faktor-faktor risiko saat neonatal yang berpengaruh terhadap risiko GPN bayi

\begin{tabular}{lcc}
\hline \multicolumn{1}{c}{ Variabel } & Rasio Hazard & $95 \%$ CI \\
\hline Kadar BIS $\geq 14,68 \mathrm{mg} / \mathrm{dL}$ & 2,5 & $0,5-12,1$ \\
Infeksi & 4,0 & $0,9-18,1$ \\
Asidosis & 1,0 & $0,3-2,9$ \\
Asfiksia & 0,6 & $0,2-1,5$ \\
Hipoglikemia & 0,8 & $0,2-4,0$ \\
Tidak mendapat fototerapi dan/atau & & \\
transfusi tukar & 2,1 & $0,8-5,6$ \\
\hline
\end{tabular}

\section{Diskusi}

Sampai saat ini belum terdapat kriteria yang jelas berapa kadar bilirubin yang dapat menyebabkan GPN pada bayi. Hal ini tidak dapat dijawab semata-mata hanya dengan angka saja, karena kadar bilirubin serum hanya merupakan satu dari berbagai faktor risiko terjadinya GPN, kecuali pada kasus-kasus yang kadarnya sangat tinggi. ${ }^{12}$

Berbagai laporan penelitian menunjukkan hasil yang cukup bervariasi mengenai hubungan GPN pada bayi dengan riwayat hiperbilirubinemia. Chen $\mathrm{YF}^{13}$ dalam penelitiannya mendapatkan bayi dengan BTS neonatal tertinggi $10-20 \mathrm{mg} / \mathrm{dL}$, memperlihatkan hasil DDST (Denver developmental screening test) yang masih dalam batas normal. Sedangkan pada kadar BTS tertinggi $>20 \mathrm{mg} / \mathrm{dL}$, didapatkan $22 \%$ mengalami gangguan pada sektor motorik kasar dan motorik halus. Yilmaz $\mathrm{Y}^{14}$ mendapatkan pada anak usia 10-72 bulan dengan riwayat BTS tertinggi $<20 \mathrm{mg} / \mathrm{dL}$ tidak menunjukkan adanya abnormalitas neurologis, sedangkan pada kadar BTS tertinggi rata-rata 20-23,9 $\mathrm{mg} / \mathrm{dL}, 9,3 \%$ mengalami diskonjugasi penglihatan. Pada kadar BTS tertinggi rata-rata $\geq 24 \mathrm{mg} / \mathrm{dL}$ didapatkan manifestasi gangguan neurologis.

Newman TB dan Klebanoff $\mathrm{M}^{15}$ mendapatkan ada hubungan bermakna antara kadar BTS $\geq 20 \mathrm{mg} / \mathrm{dL}$ dengan hasil pemeriksaan neurologis abnormal, namun tidak menemukan hubungan bermakna dengan pemeriksaan neurologis abnormal pada usia 7 tahun. Paludetto $\mathrm{R} \mathrm{dkk.}{ }^{16}$ membandingkan antara hiperbilirubinemia moderate (kadar BTS rata-rata 13,2-20 $\mathrm{mg} / \mathrm{dL}$ ) dan hiperbilirubinemia low (kadar BTS <13 $\mathrm{mg} / \mathrm{dL}$ ), didapatkan adanya indikasi perubahan yang nyata pada tingkah laku neonatus (yang dinilai dengan BNBAS) yang reversibel. ${ }^{16}$ Penelitian lain pada populasi The Collaborative Perinatal Project (CPP) menyimpulkan bahwa tidak ada abnormalitas neurologis yang konsisten pada anak dengan riwayat hiperbilirubinemia neonatal, dengan BTS $>20 \mathrm{mg} / \mathrm{dL}$ saat di follow up pada usia 7 tahun. ${ }^{17}$ Shapiro SM ${ }^{12}$ menjumpai GPN berupa ensefalopati bilirubin dengan kadar BTS $20-25 \mathrm{mg} / \mathrm{dL}$, pada kadar puncak 16-17 $\mathrm{mg} / \mathrm{dL}$, dijumpai kelainan brainstem auditory evoked response akut maupun ensefalopati bilirubin ringan (bilirubin induced neurologic disorders/ BIND). Shapiro berpendapat bahwa risiko GPN semakin meningkat bila disertai keadaan seperti prematuritas, sepsis atau penyakit inkompatibilitas.

Melihat hasil-hasil penelitian ini yang bervariasi banyak ahli yang mempunyai pandangan bahwa hiperbilirubinemia moderate dapat berhubungan dengan GPN pada neonatus aterm. Dari berbagai penelitian yang telah dilakukan, rata-rata kadar BTS $>20 \mathrm{mg} / \mathrm{dL}$ dinilai berpotensi untuk terjadinya GPN, walaupun kadar $<20 \mathrm{mg} / \mathrm{dL}$ dapat juga berpotensi terutama bila disertai adanya faktor-faktor risiko. Sejauh ini belum terdapat laporan penelitian yang menggunakan kadar BIS sebagai parameter.

Dari gambaran ROC didapatkan kadar BIS neonatal dapat digunakan sebagai prediktor risiko GPN bayi, dengan cut-off point BIS 14,68 mg/dL. Kadar BIS dipakai sebagai parameter pada penelitian ini disebabkan secara patofisiologi dapat melewati SDO, sehingga dinilai lebih berperan terhadap risiko GPN bayi.

Sawar darah otak (SDO) merupakan celah sempit antara sel-sel endotel kapiler darah yang membentuk suatu sekat antara darah dan parenkim otak. Selanjutnya SDO membentuk suatu lapisan permukaan yang besar yang berperan dalam sistem tranpor cepat nutrisi esensial yang diperlukan otak, membantu sel otak mempertahankan potensial bioelektris yang sesuai untuk konduksi impuls dan transmisi sinaptik. Termasuk juga mengatur masuknya bilirubin ke dalam otak dan mencegah difusi zatzat tertentu dari pembuluh darah ke jaringan otak. Kerusakan SDO meningkatkan permeabilitas otak 
terhadap bilirubin. ${ }^{10}$ Beberapa faktor yang menyebabkan kerusakan SDO, yang selanjutnya meningkatkan risiko GPN bayi antara lain oleh asfiksia, asidosis, hipoksia, hipoperfusi, hipoosmolaritas, infeksi/sepsis, hipoglikemia, trauma kepala, prematuritas dan sebagainya. ${ }^{3,6,7,11}$

Pada penelitian ini diteliti faktor yang mempengaruhi SDO pada subjek yang aterm, berat badan lahir $>2500 \mathrm{~g}$ dan lahir spontan. Sejauh ini penulis belum mendapatkan laporan penelitian yang mengungkapkan seberapa besar pengaruh faktor-faktor risiko tersebut terhadap risiko GPN. Kadar BIS $\geq 14,68$ $\mathrm{mg} / \mathrm{dL}$ setelah dilakukan adjustment terhadap faktor risiko lain mempunyai risiko 2,5 kali. Infeksi menyebabkan peningkatan risiko 4,0 kali. Tidak mendapat terapi menyebabkan peningkatan risiko 2,1 kali. Asidosis dan hipoglikemia saat neonatal dari hasil penelitian ini tampak bukan merupakan faktor risiko. Asfiksia pada penelitian ini tampak merupakan faktor protektif terhadap GPN (rasio hazard 0,6); pada analisis selanjutnya, didapatkan hal ini kemungkinan disebabkan kadar BIS yang lebih rendah pada bayi dengan riwayat asfiksia.

Kadar BIS $\geq 14,68 \mathrm{mg} / \mathrm{dL}$, infeksi dan hiperbiliribumia yang tidak mendapat terapi merupakan 3 faktor yang dinilai paling berperan terhadap risiko GPN bayi dengan riwayat hiperbilirubinemia, sehingga perlu perhatian intensif penanganan bayi hiperbilirubinemia yang disertai ketiga faktor risiko tersebut.

\section{Kesimpulan}

- Pada penelitian ini disimpulkan bahwa kadar BIS dapat digunakan sebagai prediktor risiko terjadinya GPN pada bayi.

- Infeksi, kadar BIS >14,68 mg/dL dan hiperbilirubinemia tidak mendapat terapi merupakan faktor yang berperan meningkatkan risiko GPN bayi dengan riwayat hiperbilirubinemia.

\section{Saran}

Perlu dilakukan penelitian untuk melihat hubungan antara kadar albumin serum sebagai zat pengikat bilirubin dalam kaitannya dengan GPN bayi dengan hiperbilirubinemia dan faktor-faktor yang mempengaruhi SDO.

\section{Daftar Pustaka}

1. Saharso D. Gangguan perkembangan neurologis. Dalam: Firmansyah A, Sastroasmoro S, penyunting. Buku Naskah lengkap KONIKA XI. Jakarta: IDAI; Juli, 1999. h. 571-88.

2. Njiokiktjien C, Panggabean R, Hartono B. Masalahmasalah dalam perkembangan psikomotor. Semarang: Wonodri Offset Ltd; 2003. h. 1-55.

3. Kliegman RM. Jaundice and hyperbilirubinemia in the newborn. Dalam: Nelson WE, Behrman RE, Kliegman R, Arvin AM, penyunting. Nelson Textbook of Pediatrics. Edisi ke-16. Philadelphia: WB Saunders Co; 2000. h. 610-6.

4. Uhudiah U, Oktavia D. Pemberian terapi sinar berdasarkan penilaian klinis pada neonatus dengan hiperbilirubinemia. Dalam: Rusdidjas, Tjipta GD, Dimyati Y, penyunting. Kongres Nasional VIII Perinasia \& Simposium Internasional. Medan: Perinasia; Oktober 2003. h. 74-81.

5. Indiarso F. Tranfusi tukar pada neonatus dengan hiperbilirubinemia. Dalam: Rusdidjas, Tjipta GD, Dimyati Y, penyunting. Kongres Nasional VIII Perinasia \& Simposium International. Medan: Perinasia; Oktober 2003. h. 84-98.

6. Porter ML, Dennis BL. Hyperbilirubinemia in the term newborn. American Family Physician 2002; 65:599-606.

7. Halamek LP, Stevenson DK. Neonatal jaundice and liver disease. Dalam: Fanaroff AA, Martin RJ, penunting. Neonatal-perinatal medicine; diseases of the fetus and infant. Edisi ke-6. New York: Mosby-Year Book Inc; 1997. h. 1345-62.

8. Rahardjani KB. Penatalaksanaan ikterus pada neonatus. Dalam: Riwanto I, Sidhartani M, penyunting. Penatalaksanaan terbaru ikterus. Semarang: BP UNDIP Semarang; 1998. h. 33-45.

9. Gomella TL, Cunningham MD, Eyal FG, Zenk KE. Hyperbilirubinemia. Dalam: Neonatology; management procedures, on-call problems, diseases and drugs. New York: Lange Medical Book/McGraw-Hill Co; 2004. h. 361-72.

10. Wilson LM. Sistem saraf. Dalam: Sylvia AP, Wilson LM, penyunting. Patofisiologi, konsep klinis proses-proses penyakit. Jakarta: EGC; 1995. h. 901-36.

11. Dennery PA, Seidmann DS, Stevenson DK. Neonatal hyperbilirubinemia. N England J Med 2001; 344:58190.

12. Shapiro SM. Bilirubin toxicity in the developing nervous system. Pediatric Neurology 2003; 29:410-21. 
13. Chen YJ, Kang WM. Effects of bilirubin on visual evoked potentials in term infants. Eur J Pediatr 1995; 154:662-6.

14. Yilmaz Y, Karadeniz L, Yildiz F, Degirmenci SY, Say A. Neurological prognosis in term newborns with neonatal hyperbilirubinemia. Indian Pediatr 2001; 38:165-8.

15. Newman TB, Klebanoff M. 33272 infants, 7-year follow-up: total serum bilirubin, tranfusions reexamined. Pediatrics 2002; 1010:32.
16. Paludetto R, Mansi G, Raimondi F, Romano A, Crivaro C, Bussi M. Moderate hyperbilirubinemia induces a transient alteration of neonatal behavior. Pediatrics 2002; 110:1-5.

17. Ip S, Chung M, Kulig J, O’Brien R, Sege R, Glicken S. An-evidence based review of Important issues concerning neonatal hyperbilirubinemia. Pediatrics 2004; 114 (1):e130-e53. 